\title{
Změny hydrologické bilance způsobené vlivem klimatických změn na území Karlovarského kraje
}

\section{ADAM BERAN, MARTIN HANEL, MAGDALENA NESLÁDKOVÁ}

Klíčová slova: vodní zdroje - model Bilan - dostupnost vodních zdrojů

\section{SOUHRN}

Na území Karlovarského kraje byly identifikovány oblasti, jež se pravidelně potýkají s problémy nedostatku vody pro vodárenské i průmyslové využití. Od roku 2015 je ve spolupráci VúV TGM, v. v. i., a státního podniku Povodí Ohře řešen projekt s názvem Zajištění dostupnosti vodních zdrojů ve vybraných oblastech Karlovarského kraje. Projekt má za úkol navrhnout opatření vedoucí k zabezpečení požadavků na užívání vod v období nedostatku vody s důrazem na maximální využití stávající infrastruktury. V článku jsou popsány identifikované pozorované změny hydrologické bilance způsobené vlivem klimatických změn na zájmovém území Karlovarského kraje, spolu se změnami výhledovými pro budoucí časové horizonty 2021-2050 a 2071-2099.

\section{ÚVOD}

S postupem klimatické změny na území České republiky vznikají pro sektor vodního hospodářství nové výzvy, se kterými se musí postupně vypořádat. Jsou již identifikovány oblasti, jež v současné době mají problémy se zabezpečením dostatku vody, a na základě hydrologického modelování jsou identifikovány oblasti, jež jsou potenciálně, kvůli vlivu klimatické změny, zranitelné $\checkmark$ budoucích časových horizontech. Problémy jsou se zabezpečením vody pro vodárenské i průmyslové účely. Článek se zaměřuje na současné a výhledové změny hydrologické bilance na území Karlovarského kraje.

V roce 2010 byla zpracována Výhledová studie potřeb a zdrojů vody v Karlovarském kraji [1], která vyhodnotila zabezpečenost požadavků na užívání vody (odběry, minimální průtoky, režimy hladin v nádržích aj.) vzhledem k dostupným kapacitám vodních zdrojů (průtokům ve vodních tocích a disponibilních zásob ve vodních nádržích). Tato studie hodnotila zabezpečenost pro

Tabulka 1. Dilčí povodín na území Karlovarského kraje (DBČ - databázové číslo, ČHP - číslo hydrologického poradí)

Table 1. Catchments of the Karlovy Vary district (DBČ - database number, ČHP- number of hydrological order)

\begin{tabular}{lllll}
\hline Dílčí povodí & $\begin{array}{l}\text { DBČ uzávěrové } \\
\text { vodoměrné stanice }\end{array}$ & ČHP & plocha povodí [km²] & výpočet odtoku \\
\hline Ohře Cheb & 206000 & $1-13-01-0140$ & 690 & - \\
\hline Odrava Jesenice & 206500 & $1-13-01-0662$ & 412 & $207300-206000-206500$ \\
\hline Ohře Citice & 207300 & $1-13-01-0910$ & 678 & - \\
\hline Teplá Březová & 212000 & $1-13-02-0212$ & 309 & $214000-212000-207300$ \\
\hline Ohře Karlovy Vary & 214000 & $1-13-02-0340$ & 821 & $216000-214000$ \\
\hline Ohře Žatec most & 216000 & $1-13-03-0280$ & 1172 & - \\
\hline Mže Stříbro & 174000 & $1-10-01-1280$ & 1144 & 393 \\
\hline Střela Čichořice & 189000 & $1-11-02-0330$ & 465 & $176100-174000$ \\
\hline Mže Hracholusky & 176100 & $1-10-01-1742$ & 388 & $190000-189000$ \\
\hline Střela Plasy & 190000 & $1-11-02-0690$ & 374 \\
\hline Blšanka Holedeč & 217000 & $1-13-03-0830$ & -
\end{tabular}


současné i výhledové hydrologické podmínky. Již ze závěrů této studie vyplývá, že na území Karlovarského kraje se nachází oblasti, které mají problémy se zabezpečením dostatku vody v bezdeštných obdobích. Tyto problémy se ukazují již v současném období a i pro výhledová období, která uvažují postup klimatických změn, těchto zranitelných oblastí podle výsledků modelování přibývá. Identifikací zranitelných oblastí a návrhem adaptačních opatření se zabýval napríklad projekt Navrhování adaptačních opatření pro snižováni dopadů klimatické změny na hydrologickou bilanci z roku 2012, který se zaměři na území povodí Orlice, Chrudimky a Blšanky [2]. Na základě definování zranitelných oblastí z hlediska nedostatku vody na území ČR v roce 2015 byl Karlovarský kraj vyhodnocen jako mírně až středně zranitelný $[3,4]$.

Od roku 2015 je ve spolupráci VúV TGM, v. v. i., a státního podniku Ohře řešen navazující projekt, jenž má za úkol vytvoření certifikované metodiky pro návrh opatření vedoucích $k$ zabezpečenosti požadavků na užívání vod v období nedostatku vody s důrazem na maximální využití stávající infrastruktury. Projekt má název Zajištění dostupnosti vodních zdrojů ve vybraných oblastech Karlovarského kraje a je spolufinancován Ministerstvem zemědělství ČR. $\checkmark$ článku jsou popsány výsledky hydrologického modelování pro dílčí povodí Karlovarského kraje, jež bylo jedním z výsledků prvního roku řešení zmiňovaného projektu. $\vee$ dalších letech budou pro boj s nedostatkem vody v rámci projektu navržena konkrétní opatření pro identifikované lokality.

\section{DATA A METODY}

Karlovarský kraj má rozlohu 3314 km². V severní části kraje leží Krušné hory s nejvyšší horou Klínovec (1244 m n. m.). Páteřní řeka Ohře rozděluje kraj přibližně $\checkmark$ polovině a odděluje Krušné hory na severu od Slavkovského lesa (Lesný, 983 m n. m.) na jihozápadě a Doupovských hor (Hradiště, 934 m n. m.) na jihovýchodě. Slavkovský les a Doupovské hory jsou od sebe oddělené největším přítokem Ohře, řekou Teplou. Mezi další významné prítoky Ohře patří Rolava, Svatava, Libocký potok, Odrava a Bystřice.

Plocha Karlovarského kraje byla pro účely hydrologického modelování rozdělena na 11 dílčích povodí o podobné rozloze, přehled se základními identifikačními údaji je uveden v tabulce 1. Pro analýzu současného stavu hydrologické bilance a pro kalibraci hydrologického modelu Bilan byla zvolena časová řada 1961-2010. K dispozici byly řady teplot, srážek a odtoku. $V$ prípadech, kdy nebyly k dispozici hodnoty odtoku prímo pro vybraný uzávěrový profil, byly hodnoty dopočítány odečtením mezipovodí (uvedeno v tabulce 1 - sloupec výpočet odtoku).

\section{Model Bilan}

Pro modelování hydrologické bilance na povodích byl použit konceptuální model Bilan simulující hydrologickou bilanci v denním či měsíčním časovém kroku, např. [5-7]. Pro potřeby modelování hydrologické bilance v předkládaném článku byl použit měsíční krok výpočtu. Vstupními daty jsou časové řady srážek a teploty vzduchu a pro kalibraci modelu i pozorovaný odtok. Model je řízen v měsíční verzi osmi volnými parametry, výpočtem se modeluje potenciální evapotranspirace, územní výpar, infiltrace do zóny aerace, průsak touto zónou, zásoba vody ve sněhu, zásoba vody v půdě a zásoba podzemní vody. Výpočet potenciální evapotranspirace je prováděn bud' výpočtem založeným na vegetačních zónách [8], nebo výpočtem založeným na slunečním záření pro určitou zeměpisnou šířku [9]. Odtok je modelován jako součet tř́ složek přímého, hypodermického a základního odtoku. V předkládaném článku se zaměřujeme na změny průměrných teplot vzduchu, srážkových úhrnů, výparu, základního odtoku a celkového odtoku.

\section{Scénáře klimatické změny}

Pro modelování budoucích změn ve veličinách hydrologické bilance byly vybrány dva budoucí časové horizonty, a sice období 2021-2050 a 2071-2099. Tato období byla vybrána na základě obdobných studií řešených ve VúV TGM, v. v. i., v posledních letech, aby byla zajištěna konzistentnost výsledků pro jejich porovnávání. K modelování dopadů klimatické změny na hydrologickou bilanci bylo vybráno celkem 15 simulací regionálních klimatických modelů (RCM), které pokrývají časové období 1961-2099. RCM jsou výstupem projektu ENSEMBLES. Všechny simulace byly ř́zené emisním scénářem SRES A1B s prostorovým rozlišením $25 \times 25$ km. Uvažováno bylo 15 RCM simulací rízených čtyřmi globálními klimatickými modely (tabulka 2). Jako výsledná hodnota změny hydrologické veličiny byl brán průměr z těchto 15 simulací. Popis vybraných regionálních klimatických modelů je uveden ve zprávě Hanel aj. [10] nebo Hanel a Vizina [11]. K dispozici byla data za pozorované období 1961-2010. Změny bilančních prvků byly brány k průměru ze současného období 1981-2010.

Tabulka 2. Přehled simulací regionálních klimatických modelü (RCM) Table 2. Regional climate model simulations (RCM)

\begin{tabular}{|c|c|c|c|}
\hline Akronym & $\mathrm{RCM}$ & $\begin{array}{l}\text { Časové } \\
\text { období }\end{array}$ & Zdroj \\
\hline \multicolumn{3}{|c|}{ řízené modelem ECHAM5 } & \multirow{19}{*}{$\begin{array}{l}{ }^{1} \text { Royal Netherlands } \\
\text { Meteorological Institute } \\
\text { (KNMI) } \\
{ }^{2} \text { Max Planck Institute } \\
\text { for Meteorology (MPI), } \\
\text { Germany } \\
{ }^{3} \text { Swedish } \\
\text { Meteorological and } \\
\text { Hydrological Institute } \\
\text { (SMHI) } \\
{ }^{4} \text { Abdus Salam } \\
\text { International Centre } \\
\text { for Theoretical Physics } \\
\text { (ICTP), Italy } \\
{ }^{5} \text { Danish Meteorological } \\
\text { Institute (DMI) } \\
{ }^{6} \text { Met Office Hadley } \\
\text { Centre, UK } \\
{ }^{7} \text { Swiss Federal Institute } \\
\text { of Technology Zurich } \\
\text { (ETHZ) } \\
{ }^{8} \text { Community Climate } \\
\text { Change Consortium for } \\
\text { Ireland (C4I) } \\
{ }^{9} \text { National Centre of } \\
\text { Meteorological Research } \\
\text { (CNRM), France } \\
{ }^{10} \text { Czech } \\
\text { Hydrometeorological } \\
\text { Institute (CHMI), Czech } \\
\text { Republic }\end{array}$} \\
\hline RACMO_EH5 ${ }^{1}$ & RACMO2.1 & $1950-2100$ & \\
\hline REMO_EH5 ${ }^{2}$ & REMO5.7 & $1951-2100$ & \\
\hline RCA_EH5 ${ }^{3}$ & RCA3.0 & $1951-2100$ & \\
\hline RegCM_EH5 ${ }^{4}$ & RegCM3 & $1951-2100$ & \\
\hline HIR_EH5 ${ }^{5}$ & HIRHAM5 & $1951-2100$ & \\
\hline \multicolumn{3}{|c|}{$\begin{array}{c}\text { řízené modely HadCM3Q0, } \\
\text { HadCM3Q3, HadCM3Q16 }\end{array}$} & \\
\hline HadRM_Q0 ${ }^{6}$ & HadRM3.0 & 1951-2099 & \\
\hline $\mathrm{CLM}_{-} \mathrm{QO}^{7}$ & CLM2. 4.6 & 1951-2099 & \\
\hline HadRM_Q3 ${ }^{6}$ & HadRM3.0 & 1951-2099 & \\
\hline RCA_Q3 ${ }^{3}$ & RCA3.0 & 1951-2099 & \\
\hline HadRM_Q16 ${ }^{6}$ & HadRM3.0 & 1951-2099 & \\
\hline RCA_Q16 ${ }^{8}$ & RCA3.0 & 1951-2099 & \\
\hline \multicolumn{3}{|c|}{ řízené modelem ARPEGE4.5 } & \\
\hline HIR_ARP ${ }^{5}$ & HIRHAM5 & $1951-2100$ & \\
\hline CNRM5_ARP ${ }^{9}$ & CNRM-RM5.1 & $1951-2100$ & \\
\hline CHMI_ARP 10 & $\begin{array}{l}\text { ALADIN- } \\
\text {-CLIMATE/ } \\
\text { CZ }\end{array}$ & $1961-2100$ & \\
\hline \multicolumn{3}{|c|}{ řízené modelem BCM2.0 driven } & \\
\hline RCA_BCM ${ }^{3}$ & RCA3.0 & $1961-2100$ & \\
\hline
\end{tabular}




\section{VÝSLEDKY}

\section{Pozorované období}

Vzhledem k dostatečně dlouhým pozorovaným časovým řadám 1961-2010 byly spočítány prưměrné hodnoty jednotlivých členů hydrologické bilance pro časové horizonty 1961-1990 a 1981-2010. V klimatologii jsou jako standardní uvažována třicetiletá období, často je pro kontrolní klima voleno období 1961-1990. Změny udávají pozorované změny hydrologické bilance. Hodnoty jsou uvedeny $v$ tabulce 3 . Změny $v$ těchto pozorovaných obdobích nejsou většinou významné, nicméně jsou již viditelné. Za zmínku stojí změna celkové prưměrné teploty o približně $0,5^{\circ} \mathrm{C}$. Při bližším pohledu na výsledky [12] je vidět největší oteplení v zimních měsících. S tímto souvisí zvýšený územní výpar během těchto měsíců. Vlivem popsaných změn se během jarního tání vsákne do podzemních zásob menší množství vod (vyšší výpar a povrchový odtok), které by měly dotovat povrchové toky během letních suchých období.

Průměrné roční srážkové úhrny se v období 1961-1990 pohybovaly v rozsahu 600-800 mm v povodí Ohře, v povodí Mže průměr nepřesahoval 650 mm, v povodí Střely 600 mm a v povodí Blšanky méně než 500 mm. V období 1981-2010 byl zaznamenán nárůst srážek v rozsahu 3-10 \%. Nejvyšší srážkové úhrny jsou dosahovány především v horských oblastech Krušných hor a Smrčin (část Krušnohorské pahorkatiny) na severu a severozápadě území. Na jihovýchodním okraji území se již naopak na srážkovém úhrnu projevuje srážkový stín Krušných hor.

Na velikosti celkového odtoku se na území Karlovarského kraje významně projevuje vliv orografie. Odtoková výška v západní a severní části území přesahuje 300 mm ročně (povodí Ohře po Cheb, Ohře po Karlovy Vary). V povodí Teplé činil prưměr približně $250 \mathrm{~mm}$. V dolní části kraje $\vee$ povodí Střely a v povodí Blšanky klesá průměrná odtoková výška díky vyšší teplotě vzduchu až pod 100 mm ročně.

\section{Budoucí změny v hydrologické bilanci}

\section{TEPLOTA}

Podle modelování hydrologické bilance na základě dat ze simulací regionálních klimatických modelů se na území Karlovarského kraje zvýší průměrná teplota vzduchu v budoucím časovém horizontu 2021-2050 o přibližně $1^{\circ} \mathrm{C}$ vzhledem $\mathrm{k}$ současnému měřenému průměru 1981-2010. Nejvíce se bude oteplovat v zimních měsících $\left(01,2^{\circ} \mathrm{C}\right)$, nejméně pak v jarních měsících $\left(00,8^{\circ} \mathrm{C}\right)$. Ve vzdálenějším časovém horizontu 2071-2099 ukazují modely zvýšení průměrné teploty o přibližně $2,7^{\circ} \mathrm{C}$ vůči současnému období. Největší oteplení vykazují zimní $\left(03,1^{\circ} \mathrm{C}\right)$ a letní měsíce $\left(03^{\circ} \mathrm{C}\right)$. $\vee$ podzimních měsících je nárůst průměrně $02,7^{\circ} \mathrm{C}, v$ jarních měsících je nárůst nejmenší o $2,2^{\circ} \mathrm{C}$. Změny průměrné teploty k časovému období 2071-2099 jsou znázorněny na obr. 1.

\section{SRÁŽKY}

Změny v průměrném ročním srážkovém úhrnu nejsou významné ani pro jeden budoucí časový horizont, v obou prípadech je změna do +7 \%. Pro dřivější časový horizont 2021-2050 vychází jarní a letní měsíce téměř beze změny, zimní a podzimní měsíce vykazují nárůst od 6 do $11 \%$ vzhledem k časovému horizontu 1981-2010. Pro vzdálenější modelové období 2071-2099 je typický vyšší nárůst průměrných srážek během zimních měsíců (13-25\%), který vyvažuje pokles během letních měsíců (7-14 \%). Změny průměrné srážky ve vzdálenějším časovém horizontu jsou znázorněny na obr. 2.

\section{ODTOKOVÁ VÝŠKA}

Průměrná roční odtoková výška se v časových horizontech 2021-2050 a 2071-2099 téměř nezmění, průměrné změny jsou do 5 \%. Pro sezonní změny je typické zvýšení odtokové výšky během zimních měsíců, pro bližší období 2021-2050 do 24 \%, pro vzdálenější časový horizont do 32 \%. V ostatních měsících v tomto období dochází k významnému snížení odtokové výšky, během letních měsíců až o $30 \%$. Změny odtokové výšky v budoucím časovém horizontu jsou znázorněny na obr. 3. Pro změny základního odtoku na povodí je typický významný úbytek během letních a také podzimních měsíců.

Změny hydrologické bilance jsou podrobněji popsány a uvedeny $v$ periodické zprávě k projektu [12].

Tabulka 3. Základni klimatické a hydrologické charakteristiky dílčich povodi Karlovarského kraje; drobné rozdilly mezi srážkami a součtem územního výparu s celkovým odtokem jsou způsobeny zménou zásob podzemní vody

Table 3. Climatic and hydrological characteristics of Karlovy Vary district catchments

\begin{tabular}{|c|c|c|c|c|c|c|c|c|c|c|}
\hline \multirow[t]{2}{*}{ Dílčí povodí } & \multicolumn{2}{|c|}{$\begin{array}{l}\text { Teplota } \\
\text { vzduchu }\left[{ }^{\circ} \mathrm{C}\right]\end{array}$} & \multicolumn{2}{|c|}{ Srážky [mm/rok] } & \multicolumn{2}{|c|}{$\begin{array}{l}\text { Pot. } \\
\text { evapotranspirace } \\
{[\mathrm{mm} / \mathrm{rok}]}\end{array}$} & \multicolumn{2}{|c|}{$\begin{array}{l}\text { Územní výpar } \\
\text { [mm/rok] }\end{array}$} & \multicolumn{2}{|c|}{$\begin{array}{l}\text { Celkový odtok } \\
{[\mathrm{mm} / \mathrm{rok}]}\end{array}$} \\
\hline & 1961-1990 & $1981-2010$ & 1961-1990 & $1981-2010$ & $1961-1990$ & 1981-2010 & 1961-1990 & $1981-2010$ & 1961-1990 & 1981-2010 \\
\hline Ohře Cheb & 6,6 & 7,1 & 795 & 833 & 529 & 552 & 474 & 501 & 319 & 328 \\
\hline Odrava Jesenice & 6,5 & 7,1 & 706 & 741 & 526 & 549 & 491 & 514 & 214 & 224 \\
\hline Ohře Citice & 6,5 & 7,1 & 687 & 734 & 527 & 549 & 446 & 467 & 241 & 264 \\
\hline Teplá Březová & 5,8 & 6,2 & 690 & 751 & 501 & 518 & 473 & 493 & 217 & 255 \\
\hline Ohře Karlovy Vary & 6,1 & 6,6 & 742 & 822 & 509 & 531 & 436 & 460 & 305 & 359 \\
\hline Ohře Žatec most & 6,9 & 7,5 & 614 & 656 & 542 & 566 & 475 & 494 & 140 & 159 \\
\hline Mže Stříbro & 6,7 & 7,2 & 642 & 682 & 536 & 556 & 445 & 462 & 197 & 217 \\
\hline Střela Čichořice & 6,2 & 6,7 & 601 & 619 & 518 & 538 & 441 & 454 & 161 & 164 \\
\hline Mže Hracholusky & 6,7 & 7,2 & 560 & 590 & 534 & 556 & 445 & 464 & 115 & 125 \\
\hline Střela Plasy & 6,9 & 7,5 & 528 & 546 & 543 & 567 & 458 & 477 & 72 & 66 \\
\hline Blšanka Holedeč & 7,6 & 8,2 & 495 & 515 & 569 & 594 & 445 & 465 & 52 & 49 \\
\hline
\end{tabular}




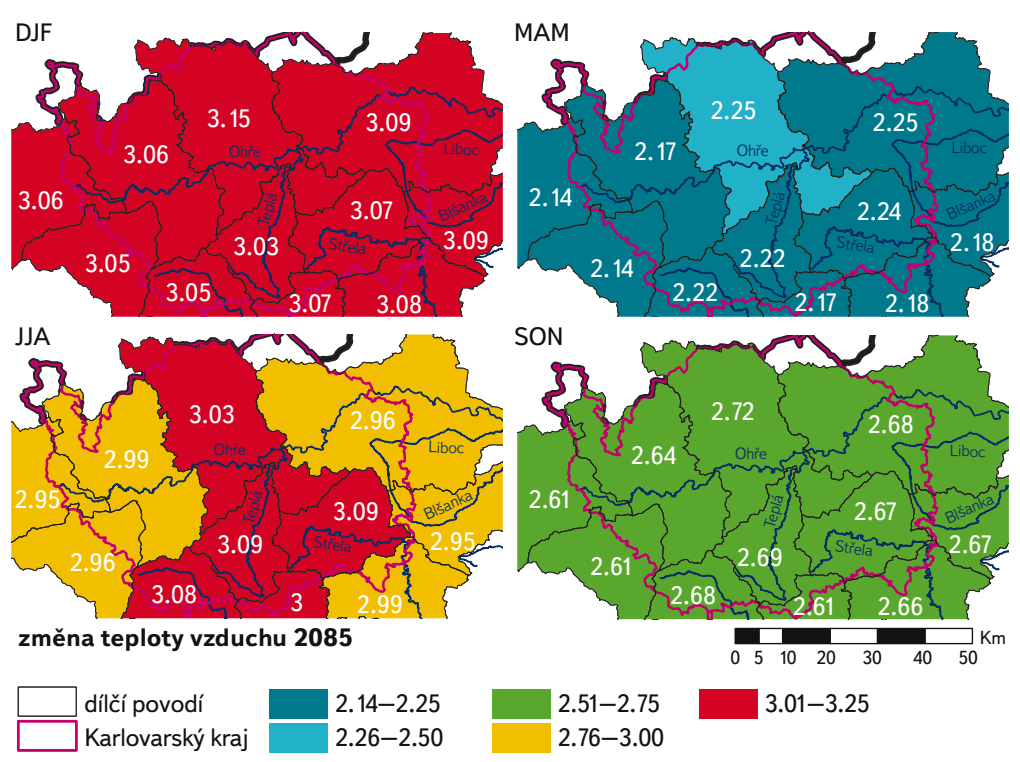

Obr. 1. Absolutní změny průměrné teploty vzduchu v časovém období 2071-2099 od současnosti 1981-2010; DJF - prosinec, leden, únor, MAM - březen, duben, květen, JJA červen, červenec, srpen, SON - září, říjen, listopad

Fig. 1. Absolute changes in mean air temperature in the scenario period 2071-2099 (with respect to 1981-2010); DJF - December, January, February, MAM - March, May, June,

JJA - June, July, August, SON - September, October, November

\section{ZÁVĚR}

Na základě modelování změn hydrologické bilance se potvrdilo, že postup klimatické změny se Karlovarskému kraji v žádném prípadě nevyhýbá. Charakter probíhajících a modelovaných změn hydrologické bilance v Karlovarském kraji je srovnatelný se změnami probíhajícími v měřítku celé České republiky. Vliv vyšších teplot vzduchu v průběhu celého roku spolu se zvýšenými srážkovými úhrny během zimy zvyšuje odtokové výšky vodních toků a zároveň zvyšuje územní výpar během tohoto období. To má za následek nedostatečnou akumulaci vody ve sněhové pokrývce, která by se během postupného jarního tání vsakovala do kolektorů podzemních vod. Dostatečné zásoby podzemních vod jsou důležité pro dotování povrchových toků základním odtokem během přelomu léta a podzimu (srpen, září), kdy je méně srážek. $V$ prípadě delších bezdeštných období, jako tomu bylo napríklad v roce 2015, se dostupnost vodních zdrojů o to zhoršuje.

Popsané změny hydrologické bilance způsobují problémy s nedostatečným zabezpečením vodních zdrojů v oblasti Karlovarského kraje. Řešený projekt Zajištění dostupnosti vodních zdrojů ve vybraných oblastech Karlovarského kraje si klade za cíl identifikovat konkrétní lokality ohrožené nedostatkem vody a navrhnout účinná adaptační opatření pro boj s nedostatkem vodních zdrojů na těchto lokalitách. Projekt je řešen ve spolupráci Vúv TGM, v. v. i., a Povodí Ohře, s. p., s předpokládaným termínem dokončení v roce 2018.
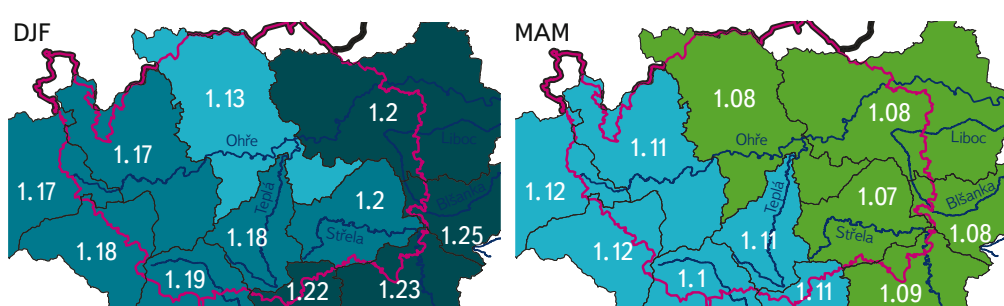

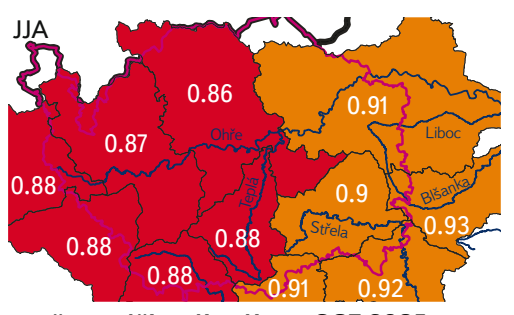

změna srážkového úhrnu SCE 2085

dílčí povodí Karlovarský kraj
$0.86-0.90$ $0.91-0.95$

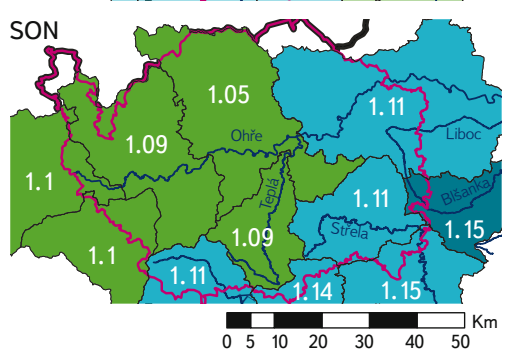

$1.06-1.10$ $1.11-1.15$

1. $16-1.20$
Obr. 2. Relativní změny průměrných srážkových úhrnů v časovém období 2071-2099od současnosti 1981-2010; DJF - prosinec, leden, únor, MAM - březen, duben, květen, JJA - červen, červenec, srpen, SON - září, říjen, listopad

Fig. 2. Relative changes in mean precipitation in the scenario period 2071-2099 (with respect to 1981-2010); DJF - December, January, February, MAM - March, May, June, JJA - June, July, August, SON - September, October, November
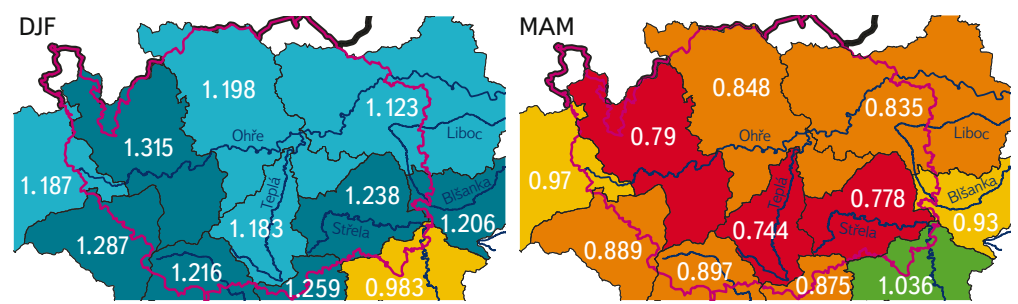

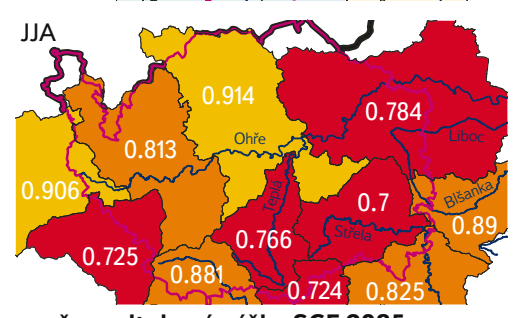

změna odtokové výšky SCE 2085

dílčí povodí

dílčí povodí
Karlovarský kraj
$0.70-0.80$ $0.81-0.90$

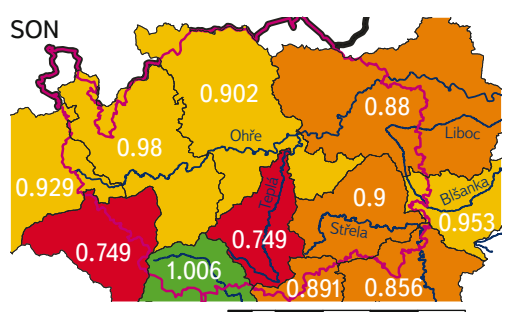

$\begin{array}{lllllllll}0 & 5 & 10 & 20 & 30 & 40 & 50\end{array}$

$1.11-1.20$
Obr. 3. Relativní změny odtokových výšek v časovém období 2071-2099 od současnost 1981-2010; DJF - prosinec, leden, únor, MAM - březen, duben, květen, JJA - červen, červenec, srpen, SON - zárí, ř́ijen, listopad

Fig. 3. Relative changes in mean runoff in the scenario period 2071-2099 (with respect to 1981-2010); DJF - December, January, February, MAM - March, May, June, JJA - June, July, August, SON - September, October, November 


\section{Poděkování}

Článek vznikl na základě výzkumu prováděného v rámci projektu Zajištění dostupnosti vodnich zdrojů ve vybraných oblastech Karlovarského kraje (QJ1520318), který je financován Ministerstvem zemědělství ČR v rámci programu KUS. Scénáre změny klimatu byly vytvořeny v rámci projektu TA02020320, který byl spolufinancován Technologickou agenturou $\check{C} R$.

\section{Literatura}

[1] VYSKOČ, P. aj. Výhledová studie potřeb a zdrojů vody v oblasti povodi Ohře a dolního Labe - východní část. Technická zpráva. Výzkumný ústav vodohospodářský T. G. Masaryka, v. v. i., a Vodohospodárský rozvoj a výstavba, a. S., Praha, 2010.

[2] MRKVIČKOVÁ, M. aj. Navrhování adaptačnich opatření pro snižování dopadů klimatické změny no hydrologickou bilanci v České republice. Technická zpráva. Výzkumný ústav vodohospodářský T.G. Masaryka, v. v. i., 2012. SBN 978-80-87402-25-2.

[3] BERAN, A. a HANEL, M. Definování zranitelných oblastí z hlediska nedostatku vody na území České republiky. Vodohospodářské technicko-ekonomické informace, 2015, 57, č. 4-5, ISSN 0322-8916.

[4] HANEL, M., BERAN, A. a KAŠPÁREK, L. Hydrologická bilance povodí 3. rádu. Technická zpráva. Praha: Výzkumný ústav vodohospodáŕský T. G. Masaryka, v. v. i., 2015.

[5] TALLAKSEN, L.M. and VAN LANEN, H.A.J. (eds). Hydrological droughts - Processes and Estimation Methods for Streamflow and Groundwater. Amsterdam, 2004

[6] VIZINA, A., HORÁČEK, S. a HANEL, M. Nové možnosti modelu BILAN. Vodohospodářské technicko-ekonomické informace, 2015, 57, Č. 4-5, ISSN 0322-8916.

[7] HORÁČEK, S. RAKOVEC, O. KAŠPÁREK, L. a VIZINA, A. Vývoj modelu hydrologické bilance - BILAN Vodohospodárské technicko-ekonomické informace, 2009, 51, mimoř. č. I, s. 2-5, ISSN 0322-8916, príloha Vodního hospodáŕství č. 11/2009.

[8] GIDROMETEOIZDAT. Rekomendatsii po roschotu ispareniia s poverhnosti suchi. St. Petersburg: Gidrometeoizdat, 1976

[9] OUDIN, L., MOULIN, L., BENDJOUDI, H., and RIBSTEIN, P. Estimating potential evapotranspiration without continious daily data: possible errors and impact on water balance simulations. Hydrological Sciences Journal, 2010, 55: 209. doi: 10.1080/02626660903546118.

[10] HANEL, M. BERAN, A. a KAŠPÁREK, L. Scénáre změny klimatu. Technická zpráva. Praha: Výzkumny ústav vodohospodářský T. G. Masaryka, v. v. i., 2015.

[11] HANEL, M. a VIZINA, A. Hydrologické modelování dopadů změn klimatu v denním kroku: korekce systematických chyb a prírůstková metoda. Vodohospodářské technicko-ekonomické informace, 2010, 52, mimoř. č. II, s. 17-21, ISSN 0322-8916, přiloha Vodního hospodárství č. 11/2010.

[12] BERAN, A. aj. Zajištěni dostupnosti vodnich zdrojü ve vybraných oblastech Karlovarského kraje. Periodická zpráva k projektu za rok 2015. Technická zpráva. Praha: Výzkumný ústav vodohospodářsky T. G. Masaryka, v. v. i., 2016

\section{Autoři}

Ing. Adam Beran',2

凶adam_beran@vuv.cz

doc. Ing. Martin Hanel, Ph.D.,2

凶martin_hanel@vuv.cz

\section{Ing. Magdalena Nesládková}

凶magdalena_nesladkova@vuv.cz

${ }^{1}$ Výzkumný ústav vodohospodářský T. G. Masaryka, v. v. i.

Česká zemědělská univerzita v Praze, Fakulta životního prostředí

Příspěvek prošel lektorským řízením.
CHANGES IN THE HYDROLOGICAL BALANCE CAUSED BY CLIMATE CHANGE IMPACTS IN THE KARLOVY VARY DISTRICT

\section{BERAN, A., ${ }^{1,2}$; HANEL, M., ${ }^{1,2}$ NESLADKOVA, M. ${ }^{1}$}

${ }^{1}$ TGM Water Research Institute, p. r. i.

${ }^{2}$ Czech University of Life Sciences Prague, Faculty of Environmental Sciences

Keywords: hydrological balance - climate change BILAN model - water resources availability

In the Karlovy Vary district, areas with lack of drinking and industrial water were identified. Since 2015, in cooperation of TGM WRI, p. r. i., and state enterprise Povodí Ohře a project called "Increasing water resources availability in selected regions of Karlovy Vary district" is financed. The objective of the project is development of methods for proposal of adaptation measures leading to increasing reliability of water resources in the periods of water stress using existing infrastructures as much as possible. The methods will be verified on pilot basins in Karlovy Vary district. The paper describes observed changes in the hydrological balance components and future changes (2021-2050 and 2071-2099) in the hydrological balance components caused by the climate change impacts on the area of Karlovy Vary district. 